ФИЛИН Никита Александрович - доктор исторических наук, доцент; заведующий кафедрой современного Востока и Африки Российского государственного гуманитарного университета (125993, Россия, г. Москва, ГСП-3, Миусская пл., 6; n.filin@rggu.ru)

ХАТУНЦЕВ Егор Вадимович - магистрант Российского государственного гуманитарного университета (125993, Россия, г. Москва, ГСП-3, Миусская пл., 6; ehatuntsev@gmail.com)

\title{
ОППОЗИЦИОННАЯ АКТИВНОСТЬ ПАРТИИ «ДВИЖЕНИЕ ЗА СВОБОДУ ИРАНА» (1989-2005 гг.)
}

\begin{abstract}
Аннотация. В статье рассматривается оппозиционная активность партии «Движение за свободу Ирана» - одной из самых известных партий левого блока в Исламской республике Иран. Хронологические рамки работы определены периодом с 1989 по 2005 гг. Это обусловлено тем, что после Исламской революции 1979 г. государственный строй страны был полностью сформирован только к 1989 г. В этом же году претерпел изменения и состав властной элиты. Новым президентом был избран Али Акбар Хашеми Рафсанджани (1989-1997 гг.), а после смерти Рухоллы Хомейни новым верховным лидером Ирана стал Али Хаменеи. Если в период 1979-1989 гг. Движение за свободу Ирана, как и ее лидер, Мехди Базарган, оставалось на политической арене, сохраняя депутатские места в парламенте, то после 1989 г. власти Ирана препятствовали любой попытке либеральных партий выдвинуть своих кандидатов на президентские и парламентские выборы. Этот факт обусловил рост оппозиционной деятельности Движения за свободу Ирана, продолжавшийся до 2002 г., когда члены партии были обвинены в установлении контактов с иностранными государствами для получения поддержки в борьбе с режимом шиитского духовенства. С этого момента и до 2005 г. активность партии снижалась и ограничивалась лишь организацией малочисленных митингов и демонстраций.
\end{abstract}

Ключевые слова: партия, оппозиция, активность, Движение за свободу Ирана

$\mathrm{C}$ момента Исламской революции в Иране (1978-1979 гг.) в противовес пришедшему к власти шиитскому духовенству во главе с аятоллой Хомейни образовалось несколько оппозиционных блоков, один из которых был представлен либеральными партиями и движениями. Его ядром стала партия «Движение за свободу Ирана» (далее - ДСИ), образованная еще в мае 1961 г. [Солтани 2019: 17]. Ее лидер Мехди Базарган был назначен на пост главы временного правительства в феврале 1979 г. [Алиев 1999: 451]. Однако со временем между Базарганом и представителями правящей группировки шиитского духовенства возросли противоречия, из-за чего в ноябре 1979 г. Базарган подал в отставку. С 1980 по 1984 г. он избирался в меджлис, тем самым сохраняя позиции ДСИ на политической арене. В то же время в 1983 г. правящая элита Ирана в лице партий шиитского духовенства запретила деятельность оппозиционных организаций, но это не помешало продолжению работы штаб-квартиры ДСИ до момента ее закрытия в 1988 г. ${ }^{1}$, что говорит о более-менее лояльном отношении властей к Движению.

Несмотря на это, ДСИ в 1989 г. предприняла попытку выставить своего кандидата на новых президентских выборах, однако она не увенчалась успехом.

В мае 1990 г. Мехди Базарган в числе других оппозиционных представителей в связи с казнью около ста политических заключенных направили президенту Хашеми-Рафсанджани (1989-1997 гг.) письмо, в котором осудили установле-

\footnotetext{
${ }^{1}$ Foreign Policy. 27.01.1989.
} 
ние «новой тирании» и потребовали восстановить конституционные свободы ${ }^{1}$. В ответ официальные власти в сентябре вынесли авторам письма приговоры за «участие в собраниях, представлявших угрозу внутренней и внешней безопасности страны, сотрудничество с внутренними и внешними врагами Исламской Республики, публикацию фальшивых сообщений с целью подрыва доверия народа к исламскому режиму, связи с иностранными радиостанциями, выступающими с контрреволюционных позиций» ${ }^{2}$. Восемь из них, среди которых был и сын Базаргана, были осуждены на сроки до 3 лет лишения свободы. Однако 14 апреля 1992 г. верховный лидер Али Хаменеи издал указ об их амнистировании ${ }^{3}$.

В начале июня 1993 г. ДСИ и ряд других оппозиционных партий призвали население Ирана бойкотировать президентские выборы. Как заявил Базарган, «ни у одной из политических партий, не входящих в правящую клику, нет шанса на участие в гонке. Наши руки, ноги и языки разбиты» 4 .

В январе 1995 г. Мехди Базарган умер, и пост лидера партии занял Ибрахим Язди. Весь год Движение пыталось получить регистрацию в Министерстве внутренних дел, но постоянно терпело неудачу. По некоторым данным, ДСИ начало распространять печатные материалы, направленные против руководящей роли духовенства. В них утверждалось, что «спасение революции лежит в возвращении священнослужителей в мечети и передаче власти светским партиям в лице ДСИ или Национального фронта» 5 .

В конце 1995 г. член ДСИ доктор Абдулькарим Соруш начинает открыто выступать против принципа «велайат-э факих» (фарси; букв. - попечительство законоведа), современной шиитской государственно-правовой доктрины, предусматривающей верховенство религиозных полномочий факиха - наиболее авторитетного знатока исламского законодательства - в сфере законодательной, исполнительной и судебной власти), и за отделение религии от государства. В начале октября он должен был выступить с изложением своих мыслей на техническом факультете Тегеранского университета, но радикально настроенные студенты не допустили этого. Имели место даже столкновения между сторонниками и противниками А. Соруша, не повлекшие, правда, серьезных последствий 6 .

В начале 1996 г. ДСИ выдвинуло в Тегеране 16 своих сторонников в качестве кандидатов на депутатские кресла в меджлисе. Однако только двум из них Наблюдательный совет дал разрешение на участие в выборах. В итоге, по словам нового лидера ДСИ Ибрахима Язди, партия решила бойкотировать выборы по причине «невозможности общения с избирателями и проведения

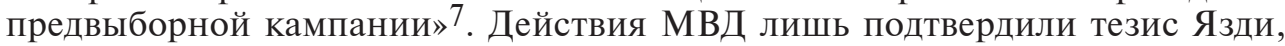
т.к. именно оно запрещало проведение предвыборных митингов Движения в Тегеранском университете, на стадионе «Шируди», а в марте полиция разогнала пресс-конференцию, организованную руководством партии, по причине нелегального статуса ДСИ 8 .

\footnotetext{
1 ИТАР-ТАСС. 17.05.1990.

2 Рейтер. 24.09.1991.

3 ИТАР-ТАСС. 30.01.1992

4 ИТАР-ТАСС. 07.06.1993.

5 ИТАР-ТАСС. 28.10.1995.

6 ИТАР-ТАСС. 13.12.1995.

7 ИТАР-ТАСС. 03.03.1996.

8 Tehran Times. 06.03.1996.
} 
Доктор А. Соруш дважды в начале года подвергался нападениям и был избит исламистами, после чего на 11 месяцев покинул Иран ${ }^{1}$.

В конце января 1997 г. была сорвана траурная церемония, посвященная второй годовщине смерти Мехди Базаргана. В разгар церемонии в тегеранском «Негах холле» была разбита емкость с отравляющим веществом. Но, несмотря на многолюдность митинга, никто из присутствовавших серьезно не пострадал ${ }^{2}$

В середине марта ДСИ выдвинуло своего кандидата на выборах в стране, которым стал Ибрагим Язди. Однако незадолго до состоявшегося в мае голосования его кандидатура была отвергнута Наблюдательным советом. Лидеры движения, включая самого Язди и вернувшегося из-за границы в середине года Абдулькарима Соруша, продолжили выступать с критикой режима и его фундаментальных основ. А в декабре был арестован издатель литературного журнала «Рах-э ноу» член ДСИ Акбар Гянджи ${ }^{3}$.

В конце января 1998 г. ДСИ провело в ряде городов страны церемонии по случаю третьей годовщины со дня смерти Мехди Базаргана. Траурные мероприятия состоялись в Тегеране, Исфахане, Зенджане, других крупных городах. В этот раз иранские власти официально санкционировали эти собрания и не чинили каких-либо препятствий их проведению. Однако во многих местах сторонники «Ансарехезболла» и «Басидж» попытались сорвать митинги. В Тегеране лишь благодаря вмешательству полиции удалось избежать столкновений. В Тебризе митинг ДСИ был все-таки сорван. Активисты «Ансарехезболла» ворвались в мечеть, где собрались члены ДСИ, устроили погром и массовую драку. При этом они скандировали, что не позволят проводить церемонии, враждебные существующему режиму4.

В феврале с обвинениями в адрес ДСИ выступил депутат парламента от Мешхеда Мохаммад Факер. Он сообщил, что располагает списком платных агентов ЦРУ в Иране, среди которых было немало членов ДСИ 5 .

В преддверии намеченных в марте довыборов в иранский парламент ДСИ выступило с заявлением, призвав граждан страны голосовать на предстоящих довыборах пустыми бюллетенями в знак протеста против решений Наблюдательного совета не допустить до выборов многих кандидатов. ДСИ призывало «К массовому участию в выборах и законной демонстрации протеста» 6 .

С декабря по апрель 2001 г. по стране прокатилась волна арестов сторонников ДСИ. В общей сложности было арестовано около 60 членов движения. Это скорее всего было вызвано давлением на действующего президента Мохаммада Хатами, чтобы тот отказался от участия в президентских выборах ${ }^{7}$. За 2001 г. были арестованы многие его сторонники, среди которых были 30 депутатов меджлиса 8 .

12 апреля 2002 г. умер один из влиятельных лидеров ДСИ Эзатолла Сахаби (1907-2002 гг.). Он был соучредителем этого движения и сыграл важную роль

\footnotetext{
1 Associated Press. 22.07.1997.

2 Iran News. 26.01.1997.

3 Iran. - Amnesty International Report. 1998. URL: https://www.amnesty.org/en/documents/ pol10/0001/1998/en/ (accessed 01.02.2022).

4 ИТАР-ТАСС. 28.01.1998.

5 ИТАР-ТАСС. 17.02.1998.

6 Iran News. 11.03.1998.

7 23.01.1380 [Иран. 12.04.2001].

8 Iran. - Amnesty International report. 2002. URL: https://www.amnesty.org/en/documents/ pol10/0001/2002/en/ (accessed 01.02.2022).
} 
в национализации иранской нефтяной промышленности в 1951 г. На его похороны собралось около 30 тыс. чел., включая выпушенных под залог членов ДСИ, студентов и оппозиционных журналистов. На митинге звучали резкие заявления о необходимости пересмотра конституции, свободы политическим заключенным и увеличении политических свобод. Никаких столкновений с радикально настроенными группами не было.

27 июля 2002 г. Исламский революционный суд Тегерана вынес приговор по делу арестованных в предыдущем году членов ДСИ. В заключении суда сообщалось, что партия «Движение за свободу Ирана» «планировала свержение высшего исламского руководства, действовала в противовес интересам национальной безопасности, пыталась изменить систему в исламской республике, участвовала в совместных мероприятиях, в том числе в собраниях и конференциях с запрещенными партиями и группировками за пределами страны, была в связях с иностранцами, в том числе и с дипломатами, пытаясь заполучить у них поддержку в осуществлении преступных действий». Также движение обвинялось в «Подготовке и распространении заявлений, лекционных пособий, интервью, слухов и лжи с тем, чтобы оказать влияние на общественное мнение и внести раскол в общество, в сборе и классификации государственных документов, в шагах, порочащих покойного имама Хомейни» 1 .

21 член этой партии был приговорен к различным срокам тюремного заключения (от 6 месяцев до 10 лет), еще 12 - к срокам от 4 месяцев до 2 лет тюрьмы и штрафам от 1200 до 6 тыс. долл. Восемь человек были приговорены к штрафам, и только 11 человек были освобождены из-под стражи в зале суда. Более того, суд вынес специальное решение, в соответствии с которым 21 член движения лишался каких бы то ни было социальных прав сроком на 10 лет. Им было запрещено участвовать в деятельности любых других политических партий и организаций страны ${ }^{2}$.

С 2002 г. активность ДСИ падает и ограничивается лишь организацией митингов. В 2005 г. либеральная оппозиция, в частности ДСИ, сосредоточилась на избирательной кампании по выборам президента. Кампания проходила достаточно бурно, и в ней на стороне кандидатов от реформаторов участвовали многие представители либеральной оппозиции. О накале страстей свидетельствует тот факт, что 11 июня, за несколько дней до выборов, в аэропорту Ахваза были жестоко избиты лидер ДСИ Ибрагим Язди и трое его сопровождающих, которые возвращались в Тегеран после участия в предвыборном митинге кандидата от реформаторов Мостафы Моина 3 .

Таким образом, можно заключить, что пик активности ДСИ, несмотря на нелегальный статус, пришелся на 1989-2001 гг. В это время ДСИ предпринимала попытки выставить своих кандидатов на парламентских и президентских выборах, однако официальные власти воспрепятствовали этому. Основной реакцией партии на действия режима стали призывы бойкотировать выборы, как, например, в 1993 г. Также в этот период члены ДСИ выступали с резкой критикой основной идеологии режима, инициировали массовые митинги и демонстрации против властей Ирана, однако завершались эти мероприятия только арестами его участников. С момента приговора Исламского революционного суда в 2002 г. в отношении ряда членов ДСИ, которых обвиняли в установлении контактов с иностранными государствами для получения под-

\footnotetext{
1 أ 07.05.1381 [Эттелеаат. 29.07.2002].

2 أن 07.05.1381 [Иран. 29.07.2002].

3 22.03.1383 [ИСНА 12.06.2005].
} 
держки в борьбе с режимом, активность партии снизилась и ограничивалась лишь организацией малочисленных митингов.

\title{
Список литературы
}

Алиев С.М. 1999. История Ирана ХХ век. М.: ИВ РАН. 648 с.

Солтани М. 2019. Движение за свободу Ирана (1961-2017 гг.) [нехзат-э азади-йе Иран (1340-1396)]. Тегеран: Институт исторических и политических исследований «Парс». 800 с.

FILIN Nikita Aleksandrovich, Dr.Sci. (Hist.), Associate Professor; Head of the Chair of Modern Eastern and African Studies, Russian State University for the Humanities (6 Miusskaya Sq, Moscow, Russia, 125993; n.filin@rggu.ru)

KHATUNTSEV Egor Vadimovich, Master's student, Russian State University for the Humanities (6 Miusskaya Sq, Moscow, Russia, 125993; ehatuntsev@gmail.com)

\section{OPPOSITIONAL ACTIVITY OF THE PARTY «FREEDOM MOVEMENT OF IRAN» (1989-2005)}

\begin{abstract}
The article examines the course of opposition activity of the Freedom Movement of Iran party, one of the most famous parties of the left bloc in the Islamic Republic of Iran. The chronological framework of the study is the period from 1989 to 2005. This is resulting from to the fact that since the Islamic Revolution in Iran in 1979, the country's current state system was fully formed only by 1989. In the same year, the composition of the power elite also underwent changes. Ali Akbar Hashemi Rafsanjani (1989-1997) was elected the new president, and after the death of Ruhollah Khomeini, Ali Khamenei became the new Supreme Leader of Iran. If in the period from 1979-1989 The Freedom Movement of Iran, like its leader Mehdi Bazargan, remained in the political arena, retaining parliamentary seats, then after 1989 the Iranian authorities prevented any attempt by liberal parties to nominate their candidates for both presidential and parliamentary elections. This fact led to the growth of the opposition activity of the Freedom Movement of Iran, which continued until 2002, when party members were accused of establishing contacts with foreign countries to gain support in the fight against the regime of the Shiite clergy. From that moment until 2005, the party's activity decreased and was limited only by organizing small rallies and demonstrations.
\end{abstract}

Keywords: party, opposition, activity, Freedom Movement of Iran 